\title{
PENYALAHGUNAAN BANTUAN SOSIAL DI LINGKUNGAN PEMERINTAH DAERAH: FAKTA NYATA DARI LAPORAN HASIL PEMERIKSAAN KEUANGAN
}

\author{
Penulis: \\ Agustinus Salle ${ }^{1}$ \\ agustinussalle@gmail.com
}

\begin{abstract}
Abstrak
This paper reveals the phenomenon of misuse of social assistance in the local government, using cases in the Papua Province. Social assistance is one type of expenditure permitted by government regulations. Social assistance is generally budgeted for poverty groups and citizens vulnerable to social risk. However, this assistance is reported to ensnare regional leaders and officials often. This study uses a case study approach. The main findings explain the vulnerability of the assistance to corruption / fraud. Corruption motivation as explained by Wolfe and Hermanson (2004) is also evident in audit study.
\end{abstract}

Keywords: Social Assistance

\section{PENDAHULUAN}

Selama empat dekade terakhir, kebijakan bantuan sosial bagi kelompok dan keluarga miskin semakin luas dilaksanakan negara berkembang (van Gils \& Yörük, 2017). Kebijakan ini mencakup spektrum luas seperti bantuan tunai langsung dan bantuan tunai bersyarat, bantuan pelayanan kesehatan gratis, an pembebasan biaya pendidikan.

Barrientos (2011) menjelaskan bahwa kebijakan dan program bantuan sosial banyak memperkenalkan pendekatan baru yang inovatif, dan dilaksanakan dalam skala besar dan luas oleh negara berkembang. Menurut dia program ini telah memberikan kontribusi yang sangat penting terhadap penurunan angka kemiskinan secara global selama dekade terakhir. Barrientos juga mengungkapkan keuanggulan program bantuan sosial dalam kebijakan anti-kemiskinan banyak negara. Data base bantuan sosial di 53 negara berkembang, termasuk Indonesia, telah dipublikasi Brooks World Poverty Institute dari The University of Manchester (Barrientos, Niño-Zarazúa, \& Maitrot, 2010).

Sejalan dengan meluasnya program bantuan sosial, anggaran yang disediakan pemerintah juga semakin bertambah (Hicks, 2018; Rubin, 2019). Di dalam negeri beragam, seperti Kartu Indonesia Sehat (KIS) dan Kartu Indonesia Pintar. Di Provnsi Papua pemerintah daerah menggunakan dana Otonomi Khusus untuk program Kartu Papua Sehat (KPS) yang membebaskan bisaya kesehatan bagi Orang Asli Papua (OAP). Penganggaran bantuan sosial yang makin meluas oleh pemerintah pusat juga diikuti

\footnotetext{
${ }^{1}$ Dosen Magister Keuangan Daerah Uncen
} 
pemerintah daerah. Kebijakan dan keberpihakan kepada warga miskin ini wajar untuk diapresiasi, namun sejumlah keresahan mulai muncul karena kebijakan ini tidak luput dari penipuan dan penyalahgunaan dana. Banyak penelitian mengusulkan perlu ada perubahan dalam pengelolaan dana termasuk meningkatkan pengawasan dan monitoring yang efektif dan berkelanjutan (Amalia \& Pratolo, 2015; Shihab, 2018) .

Literatur telah melaporkan korupsi dan fraud sangat merajalela di banyak negara berkembang. Korupsi bahkan melemahkan kebijakan dan program antikorupsi karena pejabat dan politisi terlibat dan mengejar rente (Olken \& Pande, 2012). Kirana (2014) menjelaskan korupsi sangat luas terjadi dalam masa demokrasi dan desentralisasi keuangan di Indonesia. Gejala grand corruption luas terjadi (Kurer, 2002) dan potensi mengancam bantuan sosial.

Fokus literatur bantuan sosial belum banyak menyentuh unsur fraud dan korupsi. Peneliti fokus mengkaji dan menuliskan besaran jumlah dana yang disalurkan seperti Hungary, Poland, Bulgaria, Estonia, Kyrgyz republic dan Russia pemerintah menyalurkan bantuan sebesar 9-20 persen dari GDP (Milanovic, 2000). Lain studi melihat kesalahan target (Cameron \& Shah, 2014), kuatnya pengaruh hubungan kekerabatan dalam penyaluran bantuan (Ansell \& Mitchell, 2011), debat pendekatan conditional cash transfer (Baird, Ferreira, Özler, \& Woolcock, 2014; Baird, McIntosh, \& Özler, 2011), pemberian bantuan bentuk natura atau cash (Balasubramanian, 2015). Paper ini bertujuan untuk mengenali fenomena penyalagunaan bantuan sosial yang dianggarkan dan dilaksanakan pemerintah daerah.

\section{DISAIN PENELITIAN}

Studi ini menggunakan data dari sumber Laporan Hasil Pemeriksaan (LHP) BPK. Data dari BPK merupakan sumber yang dapat dipercaya karena lembaga ini langsung mendapatkan data dari sumber, yaitu pengelola dan pelaporan keuangan pemerintah daerah. Studi ini menggunakan Buku III Laporan Hasil Pemeriksaan Kepatuhan (LHP). Buku III memuat laporan yang memuat temuan yang potensi merugikan atau sudah merugikan keuangan daerah.

Analisis data yang tersedia menggunakan qualitatifive content analysis. Analisis ini sering digunakan dalam penelitian kualitatif. Hsieh \& Shannon, (2005) mengusukan tiga pendekatan qualitative content analysis: konvensional, terarah, dan sumatif Pendekatan konvensional menganalisis data dengan 
menganalisis, menemukan konsep (konstruk) melalui kategorisasi dan pengkodean diturunkan langsung dari data teks. Dengan pendekatan terarah, analisis dimulai dengan teori atau temuan penelitian yang relevan sebagai pedoman untuk kode awal. Analisis konten sumatif melibatkan penghitungan dan perbandingan, biasanya kata kunci atau konten, diikuti oleh penafsiran konteks yang menjadi dasar penelitian. Dalam studi ini digunakan pendekatan terarah menggunakan konstruk Diamond Theory dan konsep dari peraturan pengelolaan bantuan sosial.

\section{RIVIEW LITERATUR}

\section{Bantuan sosial}

Konsep 'bantuan sosial' tidak memiliki definisi yang diterima secara internasional. Masing-masing negara memiliki program bantuan sosial, dan mendefinisikan konsep ini secara berbeda (Eardley, Bradshaw, Ditch, \& Gough, 1996). Untuk keperluan penelitian ini, penulis menggunakan definisi dari sumber peraturan. Indonesia menggunakan pengertian bantuan sosial sebagai "bantuan berupa uang, barang, atau jasa kepada seseorang, keluarga, kelompok atau masyarakat miskin, tidak mampu, dan/atau rentan terhadap risiko sosial” (Peraturan Presiden 62 Tahun 2017/Perpres 62/2017).

Peraturan Presiden menegaskan 'bantuan sosial' ditargetkan bagi kelompok warga yang tergolong miskin, tidak mampu dan atau rentan resiko sosial. Apa artinya kemiskinan? Kemiskinan secara umum diartikan sebagai kondisi di mana seseorang atau keluarga tidak dapat memenuhi kebutuhan dasarnya, seperti makanan, pakaian, tempat tinggal, pendidikan, dan kesehatan yang layak (Kumalasari \& Poerwono, 2011). Secara kuantitatif, kemiskinan adalah suatu kondisi di mana standar hidup sekelompok warga tidak memadai dan tidak layak, sedang secara kualitatif, pengertian kemiskinan adalah kondisi kehidupan manusia yang tidak layak (Kadji, 2012; Saputra \& Mudakir, 2011). Kemiskinan terkait erat dengan masalah kesejahteraan masyarakat dan menjadi ukuran dan standar kehidupan masyarakat di suatu negara. Kemiskinan telah menjadi masalah global, dan menjadi perhatian oragnisasi dunia seperti PBB dan Bank Dunia (Ravallion, 2017). Risiko Sosial adalah suatu keadaan atau peristiwa yang menyebabkan kerentanan atau ketidakmampuan warga memenuhi kebutuhan dasar sebagai dampak krisis sosial, ekonomi, politik, fenomena alam, dan bencana (Perpres 62/2017). 
Menurut Permendagri 32 tahun $2011^{2}$ tentang Pedoman Pemberian Hibah dan Bantuan Sosial yang Bersumber dari Anggaran Pendapatan dan Belanja Daerah, bantuan sosial harus dikelola secara tertib. Permendagri ini mengatur : perencanaan dan penganggaran, pelaksanaan dan penatausahaan,

1) Perencanaan dan penganggaran bantuan sosial dilaksanakan dengan tahapan:

a) warga menyampaikan usulan tertulis kepada kepala daerah,

b) Kepala daerah menunjuk OPD terkait untuk melakukan evaluasi usulan tertulis

c) Kepala OPD terkait menyampaikan hasil evaluasi dalam bentuk rekomendasi kepada kepala daerah melalui TAPD,

d) TAPD memberikan pertimbangan atas rekomendasi sesuai dengan prioritas dan kemampuan keuangan daerah.

e) Rekomendasi kepala OPD dan pertimbangan TAPD merupakan dasar pengalokasian bantuan sosial dalam anggaran daerah

f) Bantuan sosial berupa uang dicantumkan dalam RKA-OPD, sedang bantuan sosial dalam wujud barang dicantumkan dalam RKA-OPD,

g) RKA-PPKD dan RKA-OPD menjadi dasar pengalokasian bantuan sosial dalam anggaran,

h) Bantuan sosial uang dimasukkan dalam kelompok anggaran belanja tidak langsung, jenis belanja bantuan sosial, obyek belanja bantuan sosial, dan rincian obyek belanja bantuan sosial pada PPKD,

i) Bantuan sosial berupa barang dianggarkan dalam kelompok belanja langsung yang diformulasikan kedalam program dan kegiatan, yang diuraikan kedalam jenis belanja barang dan jasa, obyek belanja bantuan sosial barang dan rincian obyek belanja bantuan sosial barang yang diserahkan kepada pihak ketiga/masyarakat pada OPD,

\footnotetext{
2 Peraturan ini pertama kali ditetapkan dengan Peraturan Menteri Dalam Negeri Nomor 32 Tahun 2011 tentang Pedoman Pemberian Hibah dan Bantuan Sosial yang Bersumber dari Anggaran Pendapatan dan Belanja Daerah, dan diubah dua kali terakhir dengan Peraturan Menteri Dalam Negeri Nomor 14 Tahun 2016.
} 
j) Pimpinan daerah mencantumkan daftar calon penerima bantuan, alamat dan besaran bantuan tentang Penjabaran APBD, tidak termasuk bantuan kepada individu dan/atau keluarga yang tidak dapat direncanakan sebelumnya.

2) Pelaksanaan dan penatausahaan

a) Pelaksanaan anggaran bantuan dalam wujud uang menggunakan DPA-PPKD.

b) Pelaksanaan anggaran bantuan dalam wujud barang menggunakan dokumen DPA-OPD.

c) Kepala daerah menetapkan daftar penerima dan besaran bantuan sosial dengan keputusan kepala daerah berdasarkan peraturan daerah tentang APBD dan peraturan kepala daerah tentang penjabaran APBD.

d) Penyaluran/penyerahan bantuan sosial didasarkan pada daftar penerima bantuan sosial yang tercantum dalam keputusan kepala daerah.

e) Penyaluran/penyerahan bantuan sosial kepada individu dan/atau keluarga yang tidak dapat direncanakan sebelumnya didasarkan pada permintaan tertulis dari individu dan/atau keluarga yang bersangkutan atau surat keterangan dari pejabat yang berwenang serta mendapat persetujuan kepala daerah setelah diverifikasi oleh SKPD terkait.

f) Pencairan bantuan sosial berupa uang dilakukan dengan cara pembayaran langsung (LS).

g) Dalam hal bantuan sosial berupa uang dengan nilai sampai dengan Rp5.000.000,00 (lima juta rupiah) pencairannya dapat dilakukan melalui mekanisme tambah uang (TU).

h) Penyaluran dana bantuan sosial kepada penerima bantuan sosial dilengkapi dengan kuitansi bukti penerimaan uang bantuan sosial.

3) Pelaporan dan Pertanggungjawaban

a) Penerima bantuan sosial berupa uang menyampaikan laporan penggunaan bantuan sosial kepada kepala daerah melalui PPKD dengan tembusan kepada SKPD terkait.

b) Penerima bantuan sosial berupa barang menyampaikan laporan penggunaan bantuan sosial kepada kepala daerah melalui kepala SKPD terkait.

c) Bantuan sosial berupa uang dicatat sebagai realisasi jenis belanja bantuan sosial pada PPKD dalam tahun anggaran berkenaan. 
d) Bantuan sosial berupa barang dicatat sebagai realisasi obyek belanja bantuan sosial pada jenis belanja barang dan jasa dalam program dan kegiatan pada SKPD terkait

e) PPKD membuat rekapitulasi penyaluran bantuan sosial kepada individu dan/atau keluarga yang tidak dapat direncanakan sebelumnya paling lambat tanggal 5 Januari tahun anggaran berikutnya.

f) Rekapitulasi memuat nama penerima, alamat dan besaran bantuan sosial yang diterima oleh masing-masing individu dan/atau keluarga

g) Pertanggungjawaban pemerintah daerah atas pemberian bantuan sosial meliputi:

- Usulan/permintaan tertulis dari calon penerima bantuan sosial atau surat keterangan dari pejabat yang berwenang kepada kepala daerah;

- keputusan kepala daerah tentang penetapan daftar penerima bantuan sosial;

- pakta integritas dari penerima bantuan sosial yang menyatakan bahwa bantuan sosial yang diterima akan digunakan sesuai dengan usulan

- bukti transfer/penyerahan uang atas pemberian bantuan sosial berupa uang atau bukti serah terima barang atas pemberian bantuan sosial berupa barang.

h) Pertanggungjawaban dikecualikan terhadap bantuan sosial bagi individu dan/atau keluarga yang tidak dapat direncanakan sebelumnya.

- Laporan penggunaan bantuan sosial oleh penerima bantuan sosial;

- Surat pernyataan tanggungjawab yang menyatakan bahwa bantuan sosial yang diterima telah digunakan sesuai dengan usulan; dan

- Bukti-bukti pengeluaran yang lengkap dan sah sesuai peraturan perundangundangan bagi penerima bantuan sosial berupa uang atau salinan bukti serah terima barang bagi penerima bantuan sosial berupa barang.

i) Pertanggungjawaban sebagaimana disampaikan kepada kepala daerah paling lambat tanggal 10 bulan Januari tahun anggaran berikutnya, kecuali ditentukan lain sesuai peraturan perundangundangan.

j) Pertanggungjawaban disimpan dan dipergunakan oleh penerima bantuan sosial selaku obyek pemeriksaan. 
k) Realisasi bantuan sosial dicantumkan pada laporan keuangan pemerintah daerah dalam tahun anggaran berkenaan.

I) Bantuan sosial berupa barang yang belum diserahkan kepada penerima bantuan sosial sampai dengan akhir tahun anggaran berkenaan dilaporkan sebagai persediaan dalam neraca.

m) Realisasi bantuan sosial berupa barang dikonversikan sesuai standar akuntansi pemerintahan pada laporan realisasi anggaran dan diungkapkan pada catatan atas laporan keuangan dalam penyusunan laporan keuangan pemerintah daerah.

4) Monitoring dan Evaluasi

a) SKPD terkait melakukan monitoring dan evaluasi atas pemberian hibah dan bantuan sosial.

b) Hasil monitoring dan evaluasi disampaikan kepada kepala daerah dengan tembusan kepada SKPD yang mempunyai tugas dan fungsi pengawasan

\section{Penyalahgunaan (fraud/korupsi)}

Paper ini menggunakan konsep "penyalahgunaan dana" untuk menjelaskan berbagai prilaku individu atau kelompok pelaku fraud/korupsi yang menyebabkan pemeriksa keuangan negara menyimpulkan ada kerugian, potensi kerugian, pemborosan dan atau belanja tidak dapat diakui keberadaannya. BPK sesuai Standar Pemeriksaan Keuangan Negara melarang pemeriksa untuk membuat pernyataan farud/korupsi, karena itu merupakan kewenangan lembaga penegak hukum (BPK RI, 2017).

Korupsi atau rasuah (bahasa Latin: corruptio) adalah tindakan pejabat publik, baik politisi maupun pegawai negeri, serta pihak lain yang terlibat dalam tindakan itu yang secara tidak wajar dan tidak legal menyalahgunakan kepercayaan publik yang dikuasakan kepada mereka untuk mendapatkan keuntungan sepihak (Friedrich, 2017; Johnston, 1996; Philp, 1997). Dalam arti yang luas, korupsi adalah penyalahgunaan jabatan resmi untuk keuntungan pribadi. Dalam kenyataan, semua bentuk pemerintahan rentan terhadap korupsi.

Korupsi terjadi ketika ada tumpang tindih antara kepentingan pribadi dan kekuasaan publik. Korupsi merepresentasikan kesediaan membayar untuk pembuatan keputusan (Rose-Ackerman, 2006). Definisi umum namun sederhana tetang korupsi disampaikan Bank Dunia. Lembaga ini yang mengartikan korupsi 


\section{Jurnal Kajian Ekonomi \& Keuangan Daerah, Volume 4, Nomor 1, April 2019: 1-14}

sebagai penyalahgunaan kekuasaan publik untuk kepentingan pribadi (the abuse of public power for private benefit) (Friedrich, 2017; Vito, 1988). Korupsi menurut batasan ini terjadi di sektor publik, namun hal itu tidak berarti hanya di sektor itu saja.

Kecurangan (fraud) adalah perbuatan yang mengandung unsur kesengajaan, niat, menguntungkan diri sendiri atau orang lain, penipuan, penyembunyian atau penggelapan, dan penyalahgunaan kepercayaan yang bertujuan untuk memperoleh keuntungan secara tidak sah yang dapat berupa uang, barang/ harta, jasa, dan tidak membayar jasa, yang dilakukan oleh satu individu atau lebih dari pihak yang bertanggung jawab atas tata kelola, pegawai, atau pihak ketiga.

Beragam penjelasan teori tentang mengapa korupsi terjadi. Cressey (1953) menjelaskan ada tiga alasan terjadinya fraud/korupsi, yaitu tekanan (pressure), kesempatan (opportunity), dan rasionalisasi (rationalization) yang kemudian dikenal dengan istilah the fraud triangle theory. Tekanan adalah dorongan yang menyebabkan seseorang melakukan kecurangan. Dorongan berbuat curang karena kebutuhan atau masalah finansial, misal utang, atau ada keluarga yang sakit. Kesempatan (peluang) membuka peluang terjadinya kecurangan akibat lemahnya pengawasan. Di antara tiga elemen fraud triangle, kesempatan merupakan elemen yang paling memungkinkan untuk diminimalisir, misal melalui pernguatan Sistem Pengendalian Internal (SPI), pengawasan atasan langsung. Rasionalisasi menjadi elemen penting dalam terjadinya kecurangan karena pelaku akan mencari pembenaran atas tindakannya. Pembenaran artinya memberi pertimbangan dan penjelasan mengapa tindakan itu dilakukan. Alasan antara lain telah bekerja keras lebih dari dari orang lain dalam oranganisasi atau dia mengambang tanggungjawab yang lebi berat dan luas dalam. Rasionalisasi lain yang disampaikan Warren (2004) bahwa hal itu biasa, umum dilakukan, dan bahkan tidak melakukannya dianggap bertentangan dengan kebijakan pimpinan/atasan.

Teori berikut, fraud diamond merupakan pengembangan triangle theory dikemukakan Wolfe dan Hermanson (2004). Mereka melihat bahwa "many frauds would not have occurred without the right person with the capabilities the details of fraud". Adapun elemen-elemen dari fraud diamond theory yaitu pressure, opportunity, rationalization dan capability. Wolfe dan Hermanson berpendapat bahwa korupsi/fraud dalam jumlah besar hanya bisa terjadi bila pelaku mempunyai pengetahuan dan pengalaman. Kesempatan korupsi dapat terbuka, ada tekanan kebutuhan dan dapat dilakukan banyak orang, namun capacity harus ada. Aspek capacity memperlihatkan cara atau metode serta pendekatan yang dapat dilakukan. 


\section{HASIL DAN PEMBAHASAN}

\section{Fenomena Bantuan Sosial}

\section{Kasus 1: Anggaran yang belum dapat diprediksi}

Pada tahun 2016, Pemda Provinsi Papua menganggarkan bantuan sosial Rp.153,7 miliyar yang direalisir 94,81 persen. Hasil pemeriksaan (temuan) BPK menunjukkan penyaluran bantuan sosial yang tidak dapat direncanakan melebihi proporsi bantuan sosial yang dapat direncanakan. Peraturan menteri dalam negeri mengatur proporsi bantuan sosial yang tidak dapat direncanakan tidak melebihi proporsi yang dapat direncanakan. Kenyataan di tahun 2016, bantuan sosial yang tidak dapat direncanakan mencapai 77,76 persen, jauh lebih dibanding dengan bantuan yang direncanakan 22,24 persen.

Kepala BPKAD menjelaskan bahwa keadaan ini disebabkan karena belum adanya peraturan kepala daerah terkait ketentuan proporsi bansos yang direncanakan dan bansos yang tidak direncanakan. Kasus ini ditemukan hanya di Provinsi Papua.

\section{Kasus 2: Bukti belanja KPS tidak valid}

Provinsi Papua menggunakan dana Otonomi Khusus antara lain untuk bantuan pelayanan kesehatan bagi orang asli Papua (OAP), yang dikenal dengan nama Kartu Papua Sehat (KPS). Tahun 2016 KPS dianggarkan Rp.60 miliyar, direalisasikan 95 persen. Jaminan pembiayaan bagi peserta KPS diberikan dalam bentuk jaminan pelayanan kesehatan dasar dan jaminan pelayanan kesehatan rujukan.

Berdasarkan hasil pemeriksaan BPK atas dokumen pertanggung-jawaban kegiatan KPS diketahui masalah : (1) realisasi belanja perjalanan rujukan pasien ke fasilitas pelayanan kesehatan nasional tidak didukung dengan bukti yang lengkap, (2) terdapat belanja perjalanan rujukan pasien ke fasilitas pelayanan kesehatan nasional yang diragukan.

\section{Kasus 3: Salah peruntukan}

Penyaluran bantuan sosial kepada 130 penerima yang tidak memenuhi kriteria terkena risiko sosial, antara lain: bantuan diberikan kepada Partai Politik, bantuan kepada Asosiasi Dewan Perwakilan Rakyat Daerah Kabupaten Seluruh Indonesia (ADKASI), bantuan lembaga wartawan, Komite Nasional Pemida Indonesia (KNPI), dan bantuan panitia pemilihan duta wisata Indonesia. 
BPK menjelaskan bahwa dampak bantuan yang salah peruntukan, seperti ini, sulit untuk dinilai. Selain itu terjadi pemborosan keuangan daerah. Penyebab utama karena belum adanya mekanisme seleksi atas proposal bansos yang disampaikan warga.

\section{Kasus 4 - Masalah pelaporan}

Penerima bantuan belum menyampaikan laporan pertanggungjawaban penggunaan dana yang diterimanya. Masalah laporan dan pertanggungjawaban ini terjadi di sejumlah daerah, antara lain: Provinsi Papua, Keerom, Merauke, Nabire dan Mimika.

Terhadap masalah laporan dan pertanggungjawaban ini BPK berulangkali akibatnya : (1) belanja bantuan sosial tidak diyakini kebenarannya. (2) pemborosan keuangan daerah. Menurut BPK kondisi ini terjadi karena evaluasi terhadap penerima bantuan tidak dilakukan dan tidak optimalnya pengendalian bantuan. Rekomendasi yang diberikan kepada pemerintah daerah antara lain: meminta agar penerima bantuan segera menyampaikan laporan, meningkatkan evaluasi dan pengendalian terhadap penerima bantuan sosial.

\section{Kasus 5 -Peraturan daerah belum ada}

Permendagri No 32 tahun 2011 tentang mengharuskan pemerintah daerah menyusun dan menetapkan Peraturan Daerah tentang pengelolaan hibah dan bantuan sosial sebelum mengalokasikan bantuan sosial kepada warga. Dalam LHP BPK tahun 2016 ditemukan Kabupaten Sarmi belum menyusun dan menetapkan perda dimaksud. BPK merekomendasikan agar Bupati Sarmi segera menyiapkan dan menetapkan perda karena dasar hukum utama pemberian bantuan adalah peraturan tersebut.

\section{Kasus 6 - Daftar penerima bantuan}

Saat memberi bantuan sosial, pemerintah daerah wajib membuat keputusan kepala daerah yang menetapkan daftar penerima bantuan sosial. Dalam pemeriksaan BPK tahun 2016, BPK menemukan Kabupaten Keerom memberikan bantuan sosial dengan menetapkan keputusan kepala daerah. Namun tidak mencantumkan nama dan alamat penerima, serta jumlah bantuan. Peraturan tersebut hanya menyebutkan kelompok jenis bantuan yang diberikan. 
BPK menjelaskan bahwa penyebab masalah diatas adalah TAPD tidak berpedoman pada ketentuan yang berlaku. Atas temuan ini BPK memerintahkan kepada Kepala BPKAD dan Bendahara Bantuan Keuangan untuk menatausahakan pertangungjawaban bantuan sosial dengan baik.

\section{Kasus 7 - Tidak tertib menatausahakan bantuan}

Mekanisme penyaluran bantuan sosial secara tunai membuka peluang untuk disalahgunakan kepada para pihak yang tidak berhak menerima. Realisasi SP2D LS ke rekening bendahara bantuan selama TA 2016 adalah senilai Rp24.7 miliyar. Hasil pengujian atas mekanisme penyaluran tersebut diketahui bahwa proses penyaluran bantuan sosial diawali dengan penarikan tunai oleh saudara bendahara bantuan keuangan dari rekening bendahara bantuan melalui cheque yang sudah ditandatangani oleh Plt Kepala BPKAD dan Bendahara Bantuan Keuangan. Kemudian dari dana yang diambil disimpan oleh bendahara di kantor BPKAD untuk kemudian menunggu instruksi dari Plt Kepala BPKAD untuk diserahkan kepada penerima bantuan sosial. Setiap kali bendahara bantuan keuangan mendapatkan perintah secara tertulis untuk melakukan pembayaran, yang bersangkutan melakukan pencatatan di buku tersendiri secara manual, karena tidak semua penerima bantuan sosial dilengkapi dengan proposal permohonan.

Hasil konfirmasi terhadap 4 penerima bantuan sosial diketahui penerima bantuan sosial tersebut menerima dana bantuan sosial sesuai dengan jumlah yang dicatat oleh bendahara bantuan dalam BKU. Para penerima dana bantuan sosial tersebut belum menyampaikan laporan pertanggungjawaban penggunaan dana bantuan sosial. Berdasarkan keterangan dari penerima bantuan sosial, sebagian besar dana tersebut digunakan untuk biaya studi, berobat, uang duka dan keperluan sehari-hari.

\section{Pembahasan}

Merujuk pada teori dan peraturan yang ada pada bagian riviu literatur, penulis berpendapat bahwa fenomena fraud/korupsi bantuan sosial dari anggaran pemerintah daerah di Provinsi Papua dapat terbaca dari LHP BPK. Selain dorongan (pressure) yang sangat pribadi sifatnya, motivasi fraud/korupsi terekam baik dalam laporan hasil pemeriksaan BPK tahun 2016 di Provinsi Papua.

Kesempatan (opportunity) pelaku fraud/korupsi terungkap dalam pemeriksaan BPK, antara lain melalui: 
1) Kesempatan mengalokasikan bantuan sosial yang tidak direncanakan (Kasus 1),

2) Kesempatan dimanfaatkan pelaku dengan cara tidak membuat laporan pertanggungjawaban (Kasus 4),

3) Kesempatan diciptakan dengan melemahkan pengawasan, pengendalian dan evaluasi (Kasus 4, 6, 7).

Pembenaran (rationalisation) mengapa fraud atau korupsi dilakukan antara lain:

1) Pembenaran bantuan yang tidak direncanakan karena banyak warga yang meminta bantuan kepada pimpinan dan pejabat daerah, dan budaya Papua bahwa pimpinan dan pejabat harus membantu rakyat kebanyakan (Kasus 1)

2) Penerima bantuan yang menerima hanya sebagian kecil dar total bantuan biasa tidak melapor (Kasus 4),

3) Bantuan sosial jumlah kecil sering diminta pimpinan dan harus secara tiba-tiba, sehingga perlu menyiapkan kas kecil bantuan (Kasus 7)

Kemampuan (capacity) pelaku fraud/korupsi terekam dalam laporan pemeriksaan, antara lain :

1) TAPD memiliki kapasitas untuk menganggarkan bantuan sosial sesua arah yang diinginkan pimpinan dan pejabat daerah (Kasus 1,3)

2) Pelaksanaan pengawasan dan pengendalian yang sangat dibutuhkan untuk pengelolaan bantuan sosial relatif terabaikan, dan dapat diartikan sebagai kesengajaan tidak menggunakan kapasitas menetribkan pengelolaan keuangan (Kasus 3, 4,5, 6 dan 7)

3) TAPD dan Kepala BPKAD dipercaya telah memiliki pengetahuan tentang peraturan dan seluk beluk pengelolaan dana bantuan sosial, sehingga dipercaya trampil menilai celah-celah fraud/korupsi (Semua kasus).

Target bantuan sosial seringkali disalahgunakan, antara lain terjadi karena:

1) Bantuan diberikan kepada kelompok non target - partai politi dan wartawan

2) Bantuan sosial lebih mudah diperoleh lembaga non target karena mampu mengakses informasi dan keputusan pemberi bantuan sosial (kepala daerah, TAPD, kepala BPKAD).

3) Tidak ada evaluasi terhadap usulan proposal. 


\section{KESIMPULAN}

Kasus yang diungkapkan dalam paper ini menjelaskan bahwa bantuan sosial sangat rentan terhadap korupsi/fraud. Kecuali motivasi pressure, tiga motivasi fraud/korupsi lainnya, yaitu opportunity, rationalisation, dan capacity mempunyai contoh nyata dan jelas dalam laporan pemeriksaan keuangan BPK.

\section{KETERBATASAN}

Penggunaan kasus dalam paper ini hanya menggambarkan kondisi yang terjadi di Provinsi Papua. Kasus berbeda dapat terjadi di daerah lain. Motivasi pressure yang tidak terungkap dalam studi ini mengundang peneliti lain untuk memperluas cakupan penelitian dengan memasukkan sumber data lain, seperti sumber berita dari KPK dan pengamat masalah korupsi.

\section{DAFTAR PUSTAKA}

Amalia, C. R., \& Pratolo, S. (2015). Analisis terhadap Dugaan Pemanfaatan Belanja Hibah, Belanja Bantuan Sosial dan Belanja Bantuan Keuangan Oleh Incumbent dalam Pemilukada Serta Efektivitasnya terhadap Pendapatan Asli Daerah. Journal of Accounting and Investment, 14(1), 113.

Ansell, A., \& Mitchell, K. (2011). Models of Clientelism and Policy Change: The Case of Conditional Cash Transfer Programmes in Mexico and Brazil. Bulletin of Latin American Research, 30(3), 298-312. https://doi.org/10.1111/j.1470-9856.2010.00497.x

Baird, S., Ferreira, F. H. G., Özler, B., \& Woolcock, M. (2014). Conditional, unconditional and everything in between: a systematic review of the effects of cash transfer programmes on schooling outcomes. Journal of Development Effectiveness, 6(1), 1-43. https://doi.org/10.1080/19439342.2014.890362

Baird, S., Mclntosh, C., \& Özler, B. (2011). Cash or condition? Evidence from a cash transfer experiment. Quarterly Journal of Economics, 126(4), 1709-1753. https://doi.org/10.1093/qje/qjr032

Balasubramanian, S. (2015). Is the PDS Already a Cash Transfer? Rethinking India's Food Subsidy Policies. The Journal of Development Studies, 51(6), 642-659. https://doi.org/10.1080/00220388.2014.997221

Barrientos, A. (2011). Social assistance in developing countries. Social Assistance in Developing Countries. https://doi.org/10.1017/CBO9781139856058

Barrientos, A., Niño-Zarazúa, M., \& Maitrot, M. (2010). Social assistance in developing countries database version 5.0. Brooks World Poverty Institute Working Paper.

BPK RI. Pertaruran Badan Pemeriksa Keuangan Nomor 1 Tahun 2017 tentang Standar Pemeriksaan Keuangan Negara [Regulation of the Supreme Audit Agency Number 1/2017 concerning the State Financial Auditing Standards] (2017).

Cameron, L., \& Shah, M. (2014). Can Mistargeting Destroy Social Capital and Stimulate Crime? Evidence from a Cash Transfer Program in Indonesia. Economic Development and Cultural Change, 62(2), 381-415. https://doi.org/10.1086/674102

Cressey, D. R. (1953). Other people's money; a study of the social psychology of embezzlement.

Eardley, T., Bradshaw, J., Ditch, J., \& Gough, I. (1996). Social assistance in OECD countries: Synthesis Report. Retrieved from http://eprints. whiterose.ac.uk/73427/1/

Hicks, A. (2018). Social democracy and welfare capitalism: A century of income security politics. Cornell University Press. 
Hsieh, H.-F., \& Shannon, S. E. (2005). Three approaches to qualitative content analysis. Qualitative Health Research, 15(9), 1277-1288. https://doi.org/10.1177/1049732305276687

Kadji, Y. (2012). Kemiskinan dan Konsep teoritisnya. Guru Besar Kebijakan Publik Fakultas Ekonmi Dan Bisnis UNG.

Kirana, G. (2014). Decentralization Dilemma in Indonesia: Does Decentralization breed Corruption? Independent Study Project (ISP) Collection. Paper 1984. Retrieved from http://digitalcollections.sit.edu/isp_collection/1984

Kumalasari, M., \& Poerwono, D. (2011). Analisis Pertumbuhan Ekonomi, Angka Harapan Hidup, Angka Melek Huruf, Rata Rata lama Sekolah, Pengeluaran Perkapita dan Jumlah Penduduk terhadap Tingkat Kemiskinan di Jawa Tengah. Universitas Diponegoro. Retrieved from https://books.google.co.id/books?hl=en\&lr=\&id=GHQQI-

yzNt8C\&oi=fnd\&pg=PA34\&dq=Kemiskinan+secara+umum+diartikan+sebagai+kondisi+dimana+ses eorang+atau+keluarga+tidak+dapat+memenuhi+kebutuhan+dasarnya,+seperti+makanan,+pakaian ,+tempat+tinggal,+pendidikan,+dan

Kurer, O. (2002). Why do Voters support Corrupt Politicians? In The Political Economy of Corruption (pp. 63-86).

Milanovic, B. (2000). The Role of Social Assistance in Addressing Poverty. In J. Braithwaite, C. Grootaert, \& B. Milanovic (Eds.), Poverty and Social Assistance in Transition Countries (First Edit, pp. 99-156). New York: Palgrave Macmillan Ltd.

Olken, B. A., \& Pande, R. (2012). Corruption in Developing Countries. Annual Review of Economics, 4(1), 479-509. https://doi.org/10.1146/annurev-economics-080511-110917

Ravallion, M. (2017). Poverty comparisons. Routledge.

Rubin, I. S. (2019). The politics of public budgeting: Getting and spending, borrowing and balancing. CQ Press.

Saputra, W. A., \& Mudakir, Y. B. (2011). Analisis Pengaruh Jumlah Penduduk, PDRB, IPM, Pengangguran Terhadap Tingkat Kemiskinan Di Kabupaten/Kota Jawa Tengah. Universitas Diponegoro.

Shihab, A. N. (2018). Hadirnya Negara Di Tengah Rakyatnya Pasca Lahirnya Undang-Undang Nomor 24 Tahun 2011 Tentang Badan Penyelenggara Jaminan Sosial (The Presence Of The State Among People After The Declaration Of Law Number 24 Year 2011 Concerning Social Security Administering Agency). Jurnal Legislasi Indonesia, 9(2), 175-190.

van Gils, E., \& Yörük, E. (2017). The World Bank's social assistance recommendations for developing and transition countries: Containment of political unrest and mobilization of political support. Current Sociology, 65(1), 113-132. https://doi.org/10.1177/0011392115617310

Warren, M. E. (2004). What does corruption mean in a democracy? American Journal of Political Science, 48(2), 328-343. 